\title{
Serological survey on Ehrlichia sp. among dogs in the central region of Rio Grande do Sul
}

\author{
Pesquisa sorológica de Ehrlichia sp. em cães da região central do Rio Grande do Sul
}

Felipe da Silva Krawczak ${ }^{1 *}$; Marcelo Bahia Labruna'; Luís Antônio Sangioni²; Fernanda Silveira Flores Vogel²; João Fabio Soares ${ }^{1}$; Sônia Terezinha dos Anjos Lopes ${ }^{3}$

\begin{abstract}
${ }^{1}$ Departamento de Medicina Veterinária Preventiva e Saúde Animal, Faculdade de Medicina Veterinária e Zootecnia, Universidade de São Paulo - USP, São Paulo, SP, Brasil

${ }^{2}$ Departamento de Medicina Veterinária Preventiva, Centro de Ciências Rurais - CCR, Universidade Federal de Santa Maria - UFSM, Santa Maria, RS, Brasil

${ }^{3}$ Departamento de Clínica de Pequenos Animais, Centro de Ciências Rurais - CCR, Universidade Federal de Santa Maria - UFSM, Santa Maria, RS, Brasil
\end{abstract}

Received January 17, 2012

Accepted May 21, 2012

\begin{abstract}
A serological survey on Ehrlichia canis was conducted among dogs in the central area of the state of Rio Grande do Sul, where the tick Rhipicephalus sanguineus is a common parasite of dogs. Out of a total of $316 \mathrm{dogs}$ attended at the veterinary teaching hospital in the municipality of Santa Maria, only $14(4.43 \%)$ reacted positively to E. canis antigens in the indirect immunofluorescence assay, with the following endpoint titers: 80 (three dogs), 160 (five), 320 (four), 640 (one) and 1280 (one). Like in previous studies in other regions of the state of Rio Grande do Sul, only a very small portion of the dogs in Santa Maria presented antibodies reactive to E. canis, even though canine infestations due to $R$. sanguineus are very common in this study region. These results contrast with other regions of Brazil, where $E$. canis is endemic among canine populations, with seropositivity values generally higher than $30 \%$. Genetic differences among the R. sanguineus populations in South America might be implicated in these contrasting results.
\end{abstract}

Keywords: Ehrlichia canis, Rio Grande do Sul, serology, dogs.

\section{Resumo}

Foi realizada uma pesquisa sorológica para Ehrlichia canis, em cáes, na região central do estado do Rio Grande do Sul, onde o carrapato Rhipicephalus sanguineus é um parasita comum em cáes. De um total de 316 cáes atendidos no Hospital Veterinário Universitário no Município de Santa Maria, somente 14 (4,43\%) reagiram positivamente para o antígeno de E. canis pela reaçáo de imunofluorescência indireta, com os seguintes títulos finais: 80 (3 cáes), 160 (5), 320 (4), 640 (1) e 1.280 (1). Semelhante aos estudos anteriores em outras regióes do estado do Rio Grande do Sul, apenas uma pequena parcela dos cáes de Santa Maria apresentaram anticorpos reativos para E. canis, mesmo que as infestaçóes caninas por $R$. sanguineus sejam muito comuns na regiáo de estudo. Esses resultados contrastam com outras regiôes do Brasil, nas quais E. canis é endêmica entre a população canina, com valores de soropositividade geralmente superiores a 30\%. Diferenças genéticas entre as populaçóes de R. sanguineus, na América do Sul, poderiam estar envolvidas nesses resultados contrastantes.

Palavras-chave: Ehrlichia canis, Rio Grande do Sul, sorologia, cães.

Ehrlichia canis is the etiological agent of canine monocytic ehrlichiosis (CME), a tick-borne disease that affects domestic dogs around the world (YU et al., 2007). The agent is primarily transmitted by the nymphs and adults of the brown dog tick, Rhipicephalus sanguineus (VIEIRA et al., 2011). Since there is no transovarial (vertical) transmission of E. canis in ticks

\footnotetext{
*Corresponding author: Felipe da Silva Krawczak

Departamento de Medicina Veterinária Preventiva e Saúde Animal,

Faculdade de Medicina Veterinária e Zootecnia, Universidade de São Paulo - USP, Av. Prof. Dr. Orlando Marques de Paiva, 87, Cidade Universitária,

CEP 05508-270, São Paulo, SP, Brasil

e-mail: fkrawczak@yahoo.com.br
}

(GROVES et al., 1975), and because dogs usually develop long-lasting infection, dogs are incriminated as the primary reservoirs of E. canis in nature (HARRUS et al., 1998; WANER et al., 2001). A recent review study showed that $E$. canis generally occurs endemically in Brazil (VIEIRA et al., 2011). However, it is noteworthy that seropositivity to E. canis among different canine populations was generally greater than $30 \%$ in all Brazilian regions, except for the southern region, where the lowest frequency of seropositivity to E. canis in Brazil has been reported (VIEIRA et al., 2011). For example, $1.7 \%$ and $4.8 \%$ were reported in previous studies in the state capital and the southern region, respectively, of the state 
of Rio Grande do Sul (LABARTHE et al., 2003; SAITO et al., 2008). Even though much lower winter temperatures generally occur in southern Brazil, this different climatic condition does not preclude establishment of $R$. sanguineus, which is a very common parasite of dogs in Rio Grande do Sul, especially in urban areas (RIBEIRO et al., 1997; EVANS et al., 2000). Here, we determined the seropositivity to E. canis among dogs in the central area of the state of Rio Grande do Sul, where R. sanguineus is a common parasite of dogs and no serological survey study had previously been done.

Between March and June 2010, blood serum samples were collected from 316 dogs attended at the veterinary teaching hospital of the Federal University of Santa Maria, located in the municipality of Santa Maria (29 $41^{\prime} \mathrm{S}$ and $\left.53^{\circ} 48^{\prime} \mathrm{W}\right)$. All the dogs were owned by clients of the veterinary practice and were brought to the hospital for routine clinical procedures not necessarily related to vector-borne diseases. Canine serum samples were tested by means of the immunofluorescence assay (IFA) against crude antigens of the E. canis strain São Paulo (AGUIAR et al. 2008), prepared in a cell culture as previously described (AGUIAR et al., 2007). Reactions were performed with FITC-labeled anti-dog IgG (Sigma-Aldrich) that had previously been titrated to the best working dilution (1:800), as described previously (RISTIC et al., 1972; AGUIAR et al., 2007). Serum was considered to contain antibodies reactive to E. canis if it displayed a reaction at the 1:80 dilution. On each slide, a serum sample that had previously been shown to be nonreactive (negative control) and one that was known to be reactive (positive control; endpoint titer of 1280) were tested at the 1:80 dilution. These control serum samples were derived from the study by Aguiar et al. (2007). Samples that reacted at the screening dilution (1:80) were then titrated using serial two-fold dilutions to determine endpoint titers.

A total of $14 \mathrm{dog}$ serum samples (4.43\%) reacted positively to $E$. canis antigens using IFA, with the following endpoint titers: 80 (three dogs), 160 (five), 320 (four), 640 (one) and 1280 (one). Like in previous studies (LABARTHE et al., 2003; SAITO et al., 2008), we found that only a very small portion of the canine population of Santa Maria presented antibodies reactive to E. canis, even though canine infestations by $R$. sanguineus are very common in this study region (unpublished data).

In a recent genetic study on ticks from different populations of $R$. sanguineus in Latin America, Moraes-Filho et al. (2011) demonstrated that the taxon $R$. sanguineus is likely to be represented by at least two distinct species in Latin America: one restricted to southern South America (Chile, Argentina, Uruguay and the state of Rio Grande do Sul), and another encompassing the remaining areas of Latin America, from Mexico to Brazil (excluding Rio Grande do Sul). It is possible that this supposedly distinct Rhipicephalus tick species that occurs in Rio Grande do Sul, Chile, Argentina, and Uruguay is not competent to transmit $E$. canis, although this condition has yet to be confirmed experimentally. Interestingly, one study in Uruguay failed to detect Ehrlichia DNA in 180 R. sanguineus ticks (VENZAL et al., 2007). In addition, there has not been any molecular study to prove the existence of E. canis in ticks or dogs in Rio Grande do Sul, or in Chile, Uruguay and Argentina, where $R$. sanguineus is also the major tick species infesting domestic dogs (GONZÁLES-ACUNAA; GUGLIELMONE,
2005; GUGLIELMONE; NAVA, 2005; VENZAL et al., 2007). A similar scenario is found in Rio Grande do Sul (RIBEIRO et al., 1997; VIEIRA et al., 2011). Finally, because serologically based studies are not species-specific (WANER et al., 2001), it is also possible that the few serologically positive dogs in the present study were infected by another Ehrlichia species, or even by an agent belonging to another genus of Anaplasmataceae that is yet to be identified in southern Brazil. In fact, the low endpoint titers presented by the dogs are compatible with cross-reactions.

\section{Acknowledgements}

This study was supported by the Research Support Foundation of the State of São Paulo (Fundação de Amparo à Pesquisa do Estado de São Paulo, FAPESP) and the National Council for Scientific and Technological Development (Conselho Nacional de Desenvolvimento Científico e Tecnológico, CNPq).

\section{References}

Aguiar DM, Saito TB, Hagiwara MK, Machado RZ, Labruna MB. Diagnóstico sorológico de erliquiose canina com antígeno brasileiro de Ehrlichia canis. Cienc Rural 2007; 37(3): 796-802. http://dx.doi. org/10.1590/S0103-84782007000300030

Aguiar DM, Hagiwara MK, Labruna MB. In vitro isolation and molecular characterization of an Ehrlichia canis strain from São Paulo, Brazil. Braz J Microbiol 2008; 39(3): 489-493. http://dx.doi.org/10.1590/S151783822008000300014

Evans DE, Martins JR, Guglielmone AA. A review of the ticks (Acari: Ixodida) of Brazil, their hosts and geographic distribution - 1. The state of Rio Grande do Sul, Southern Brazil. Mem Inst Oswaldo Cruz 2000; 95(4): 453-470. PMid:10904399. http://dx.doi. org/10.1590/S0074-02762000000400003

González-Acuña D, Guglielmone AA. Ticks (Acari: Ixodoidea: Argasidae, Ixodidae) of Chile. Exp Appl Acarol 2005; 35(1-2): 147-163. PMid:15777007. http://dx.doi.org/10.1007/s10493-004-1988-2

Groves MG, Dennis GL, Amyx HL, Huxsoll DL. Transmission of Ehrlichia canis to dogs by ticks (Rhipicephalus sanguineus). Am J Vet Res 1975; 36(7): 937-940. PMid:1147359.

Guglielmone AA, Nava S. Las garrapatas de la familia Argasidae y de los géneros Dermacentor, Haemaphysalis, Ixodes y Rhipicephalus (Ixodidae) de la Argentina: distribución y hospedadores. Rev Invest Agrop 2005; 34(2): 123-141.

Harrus S, Waner T, Aizenberg I, Foley JE, Poland AM, Bark H. Amplification of ehrlichial DNA from dogs 34 months after infection with Ehrlichia canis. J Clin Microbiol 1998; 36(1); 73-76. PMid:9431923 PMCid:124810.

Labarthe N, Campos MP, Barbarini O, Mckee W, Coimbra CA, Hoskins J. Serologic prevalence of Dirofilaria immitis, Ehrlichia canis, and Borrelia burgdorferi infections in Brazil. Vet Ther 2003; 4(1): 67-75. PMid:12756637.

Moraes-Filho J, Marcili A, Nieri-Bastos FA, Richtzenhain LJ, Labruna MB. Genetic analysis of ticks belonging to the Rhipicephalus sanguineus group in Latin America. Acta Trop 2011; 117(1): 51-55. PMid:20858451. http://dx.doi.org/10.1016/j.actatropica.2010.09.006 
Ribeiro VLS, Weber MA, Fetzer LO, Vargas CRB. Espécies e prevalência das infestaçôes por carrapatos em cães de rua da cidade de Porto Alegre, RS, Brasil. Cienc Rural 1997; 27(2); 285-289. http://dx.doi.org/10.1590/ S0103-84781997000200019

Ristic M, Huxsoll DL, Weisiger RM, Hildebrandt PK, Nyindo MBA. Serological diagnosis of tropical canine pancytopenia by indirect immunofluorescence. Infect Immun 1972; 6(3): 226-231. PMid:4118045 PMCid:422520.

Saito TB, Cunha-Filho NA, Pacheco RC, Ferreira F, Pappen FG, Farias NAR, et al. Canine Infection by Rickettsiae and Ehrlichiae in Southern Brazil. Am J Trop Med Hyg 2008;79(1):102-108. PMid:18606772.

Venzal JM, Agustín EP, Castro O, De Souza CG, Portillo A, Oteo JA. Study on seasonal activity in dogs and ehrlichial infection in Rhipicephalus sanguineus (Latreille, 1806) (Acari: Ixodidae) from southern Uruguay.
Parasitol Latinoam 2007; 62(1-2):23-26. http://dx.doi.org/10.4067/ S0717-77122007000100004

Vieira RFC, Biondo AW, Guimarães AMS, Santos AP, Santos RP, Dutra LH, et al. Ehrlichiosis in Brazil. Rev Bras Parasitol Vet 2011; 20(1): 1-12. PMid:21439224. http://dx.doi.org/10.1590/ S1984-29612011000100002

Waner T, Harrus S, Jongejan F, Bark H, Keysary A, Cornelissen AW. Significance of serological testing for ehrlichial diseases in dogs with special emphasis on the diagnosis of canine monocytic ehrlichiosis caused by Ehrlichia canis. Vet Parasitol 2001; 95(1): 1-15. http://dx.doi. org/10.1016/S0304-4017(00)00407-6

Yu XJ, McBride JW, Walker DH. Restriction and expansion of Ehrlichia strain diversity. Vet Parasitol2007; 143(3-4): 337-346. PMid:16996215. http://dx.doi.org/10.1016/j.vetpar.2006.08.027 